\title{
NON DISCLOSURE AGREEMENT SEBAGAI PERLINDUNGAN HAK KEKAYAAN INTELEKTUAL DALAM PERJANJIAN KERJASAMA
}

\author{
Asry Rismawaty \\ Program Studi Magister Ilmu Hukum \\ Pascasarjana Universitas Islam Bandung \\ Email : a.asrylaw@gmail.com
}

\begin{abstract}
Abstarak- Perjanjian Kerahasiaan atau yang sering disebut dengan NonDisclosure Agreement semakin dirasa pelu digunakan dalam setiap perjanjian kerjasama sebagai bentuk dari perlindungan Hukum Kekayaan Intelektual. Penelitian ini bertujuan untuk mengetahui dan memahami urgensi pentingnya informasi rahasia dibuat atau dicantumkan dalam suatu klausula perjanjian kerjasama. Penelitian ini menggunakan metode pendekatan yuridis normatif, dengan spesifikasi yaitu deskriptif analitis. Data yang digunakan adalah data sekunder yang diperoleh dari studi kepustakaan. Hasil dari penelitian ini menunjukkan bahwa dengan adanya perjanjian kerahasiaan dalam suatu perjanjian kerjasama dapat melindungi dan melindungi para pihak yang berkepentingan.
\end{abstract}

Kata Kunci: Perjanjian Kerahasiaan, Informasi Rahasia, Rahasia Dagang, Hukum Kekayaan Intelektual

Abstract- Non-Disclosure Agreements are increasingly felt necessary to be used in every cooperation agreement as a form of protection of Intellectual Property Law. This study aimed at determining and understanding the urgency of confidential information created or included in a cooperation agreement clause. This study used a normative juridical approach with a descriptive-analytical specification. The data used secondary data obtained from literature study. The result indicates that Non-Disclosure Agreements in a cooperation agreement can protect the parties concerned.

Keyword : Non-Disclosure Agreement, Confidential Information, Trade Secrets, Intellectual Property Law

\author{
A. PENDAHULUAN \\ Hak Kekayaan Intelektual \\ merupakan suatu hak yang timbul \\ akibat adanya tindakan kreatif \\ manusia yang menghasilkan \\ karyakarya inovatif yang dapat
}

diterapkan dalam kehidupan
manusia. Saat ini terdapat
beberapa istilah yang digunakan
untuk memberikan pengertian
terhadap hak tersebut yang
merupakan terjemahan dari


Intellectual Property Rights (IPR). Istilah lain yang digunakan untuk terjemahan IPR adalah Hak Milik Intelektual.

Sehubungan dengan hal tersebut di atas, Abdulkadir Muhammad mengemukakan bahwa : Kata "milik" lebih tepat digunakan daripada kata "kekayaan" karena alasan bahwa pengertian "hak milik" memiliki ruang lingkup yang lebih spesifik dibandingkan dengan istilah “kekayaan”. Dalam sistem Hukum Perdata Indonesia sendiri hukum harta kekayaan justru terdiri dari dua bagian yaitu hukum perikatan dan hukum benda.

Permasalahan hak kekayaan intelektual semakin kompleks, karena tidak semata-mata memberikan perlindungan terhadap individu akan tetapi telah menjadi bagian dari masalah politik dan ekonomi. Permasalahan HKI sudah tidak murni lagi hanya bidang hak kekayaan intelektual semata, karena banyak kepentingan yang berkaitan dengan HKI tersebut, bidang ekonomi dan politik sudah menjadi unsur yang tidak terpisahkan dalam permasalahan HKI (Djumhana dan Djubaedillah, 1997: 8).

Hak milik intelektual memiliki lingkup yang snagat luas. Sudargo Gautama membagi hak milik intelektual menjadi dua, yaitu karya-karya di bidang hak cipta (copyrights) dan hakhak yang terkait serta hak milik industry (industrial propertyrights). Secara sederhana hak cipta berkaitan dengan karya kreatif dibidang seni, sastra dan ilmu pengetahuan, sedangkan hak milik industry dalam macam dan jenisnya semakin berkembang sesuai dengan perkembangan ilmu pengetahuan dan teknologi.

Dengan selesainya Uruguay Round pada tanggal 15 Desember 1994, telah diterima pembentukan World Trade Organization (WTO) dalam bentuk Agreement Establishing the Multilateral Trade Organization. Final Act dari putaran Uruguay tersebut. Salah 
$\begin{aligned} & \text { satunya adalah Persetujuan } \\ & \text { tentang aspek-aspek yang } \\ & \text { berhubungan dengan }\end{aligned}$
perdagangan dari hak milik
intelektual atau Agreement on

Trade Related Aspect of Intellectual Property Right (TRIPs) (Gautama, 1994: 2). Indonesia telah meratifikasi persetujuan tersebut dengan Undang-undang No. 7 Tahun 1994. Sebagai konsekuensinya, Indonesia harus tunduk pada persetujuan yang telah disepakati. Salah satu upaya yang dilakukan Indonesia di bidang HKI adalah dengan melakukan penyempurnaan dan penambahan peraturan perundang-undangan sehingga pada tahun 2000, 2001, dan 2002 Dewan Perwakilan Rakyat telah mengesahkan beberapa peraturan perundang-undangan di bidang HKI. Undang-undang tersebut, adalah:

a. UU No. 29 Tahun 2000 tentang Perlindungan Varietas Tanaman;

b. UU No. 30 Tahun 2000 tentang Rahasia Dagang; c. UU No. 31 Tahun 2000 tentang Desain Industri;

d. UU No. 32 Tahun 2000 tentang Tata Letak Sirkit Terpadu;

e. UU No. 13 Tahun 2016 tentang Paten;

f. UU No.20 Tahun 2016 tentang Merek;

g. UU No 28 tahun 2014 tentang Hak Cipta.

Rahasia dagang merupakan suatu informasi yang terdapat kerahasiaan di dalamnya tidak terkecuali dengan Non-disclosure Agreement atau NDA yang dikenal sebagai suatu perjanjian kerahsiaan yang lazim digunakan dalam suatu kerjasama atau ikatan pekerja dengan pengusaha ataupun dalam suatu kerjasama antara Para Pihak untuk melindungi suatu informasi rahasia milik Pihak Yang Mengungkapkan.

Non-disclosure Agreement yang dikenal sebagai Perjanjian Kerahasiaan adalah suatu hukum kontrak antara para pihak yang memberikan kewenangan untuk meberikan suatu informasi rahasia 
yang diungkapkan oleh pihak yang mengungkapkan kepada pihak yang menerima informasi untuk tujuan tertentu baik perjanjian kerja maupun untuk kepentingan bisnis.

"Informasi rahasia" merupakan suatu dan semua informasi dalam bentuk apapun, baik tertulis maupun dalam format elektronik, lisan atau sebaliknya, baik yang dianggap sebagai "Rahasia" maupun tidak, termasuk tetapi tidak terbatas pada, informasi yang berkaitan dengan bisnis, keadaan keuangan, strategi pemasaran, metode usaha, cara/kiat, penyedia, pelanggan, operasi, pentarifan, informasi teknis, ketentuan dan syarat kontrak serta semua informasi dalam bentuk apapun yang berkaitan dengan salah satu Pihak, pemegang saham dan/atau perusahaan terkait dan asosiasi yang disampaikan, diserahkan atau disebarkan oleh atau atas nama salah satu Pihak kepada Pihak lainnya atau kepada Pegawai-nya, dengan maksud atau berkaitan dengan Proyek, baik sebelum maupun sesudah tanggal efektif suatu perjanjian.

Perjanjian kerahasiaan yang diatur dalam kontrak kerjasama maka landasan hukumnya kurang lebih mengacu pada pasal 1338 Kitab Undang-Undang Hukum Perdata (KUHPer) berbunyi:

"Seтиa persetujuan yang dibuat sesuai dengan undangundang berlaku sebagai undangundang bagi mereka yang membuatnya. Persetujuan itu tidak dapat ditarik kembali selain dengan kesepakatan kedua belah pihak, atau karena alasan-alasan yang ditentukan oleh undangundang. Persetujuan harus dilaksanakan dengan itikad baik." Pemeliharaan rahasia berkaitan dengan hubungan kerjasama baik hubungan antara pekerja dan pengusaha maupun untuk hubungan dalam suatu hubungan kerjasama bisnis dimana salah satu pihak atau keduanya berkewajiban untuk menjaga rahasia.

"Informasi Rahasia" selalu berkaitan dengan Hak Kekayaan Intelektual baik berupa paten, hak 
atas invensi, hak cipta dan hakhak yang terkait, hak moral, hak jasa, merek dagang, nama usaha dan nama domain, hak atas desain suatu produk (rights in get-up), muhibah (goodwill) dan hak untuk menuntut atas pernyataan palsu (passing off) atau persaingan tidak sehat, hak atas rancangan, hak atas perangkat lunak komputer, hak basis data, hak untuk menggunakan, dan melindungi kerahasiaan, informasi rahasia (termasuk pengetahuan dan rahasia dagang) dan semua hak kekayaan intelektual lainnya, baik yang terdaftar maupun tidak terdaftar dan termasuk semua permohonan dan hak untuk mengajukan permohonan dan untuk memperoleh pembaruan atau perpanjangan, dan hak untuk mengklaim prioritas dari, hak-hak tersebut dan semua hak serupa atau setara atau bentuk-bentuk perlindungan yang berlaku atau akan berlaku saat ini atau di kemudian hari di bagian mana pun di dunia.

Sudikno Mertokusumo berpendapat bahwa HAKI merupakan hak milik yang bersifat mutlak yang tidak bersifat kebendaan yang obyeknya adalah hasil pemikiran manusia, suatu pendapat, tanda atau penemuan.

Bahwa dalam melakukan kerjasama baik antara pekerja dan pengusaha maupun dengan rekan bisnis para pihak yang melakukan kerjasama sebaiknya dapat mengelola dan mengontrol informasi rahasia agar tidak tersebar dan menimbulkan kerugian bagi para pihak. Salah satu langkah awal atau langkah pertama yang dapat dilakukan adalah dengan cara melakukan pengaturan dalam perjanjian kerjasama untuk menjaga informasi rahasia dengan non disclosure agreement.

\section{B. HASIL DAN PEMBAHASAN}

Dalam sistem Hukum Perdata di Indonesia, dimana dapat dikatakan HKI sebagai hak kebendaan, yang merupakan hak atas suatu benda, yang bersumber dari hasil karya otak atau hasil kerja rasio otak manusia yang menalar dan hasil kerjanya itu 
merupakan benda immaterial (benda tidak berwujud).

\section{Pemilik Rahasia Dagang} wajib memelihara dan menjaga kerahasiaan dari informasi yang dimilikinya. Hal itu dapat dilakukan melalui berbagai langkah seperti melalui pembuatan kontrak yang isinya secara eksplisit mewajibkan pihak lain untuk tidak membocorkan rahasia itu secara tertulis. Kontrak tertulis semacam ini akan sangat membantu khususnya untuk menghindarkan kesalah pahaman atas ruang lingkup yang harus dirahasiakan. Kewajiban dalam memelihara kerahasiaan ini juga ddapat ditempuh melalui pembuatan ketentuan-ketentuan kontrak yang bersifat implisit. Pada prinsipnya hukum akan melindungi kerahasiaan itu berdasarkan asas-asas hukum perjanjian yang menyatakan bahwa perjanjian itu tidak hanyha mencakup apa yang telah secara eksplisit diperjanjikan, tetapi juga mencakup kebiasaan-kebiasaan meskipun tidak secara tegas dinyatakan seperti tercantum dalam Pasal 1347 BW yang berbunyi :

"Hal-hal yang menurut kebiasaan selamanya diperjanjikan, dianggap secara diam-diam dimasukkan dalam persetujuan, meskipun tidak dengan tegas dinyatakan"

Demikian juga halnya, bahwa perjanjian itu harus ditafsirkan secara luas dalam kaitan dengan hubungan satu janji dengan janji lainnya, sehingga tiap janji harus ditafsirkan secara sistematis dalam rangka persetujuan secara keseluruhan. Hal ini sejalan dengan ketentuan Pasal 1348 BW yang berbunyi :

"Semua janji yang dibuat dalam suatu persetujuan, harus diartikan dalam hubungan satu sama lain; tiap janji harus ditafsirkan dalam rangka persetujuan seluruhnya”.

Jika dikaitkan dengan perlindungan asas Rahasia Dagang, maka pihak yang telah melanggar hak-hak atas suatu informasi rahasia yang dimiliki seseorang yang memiliki nilai komersial dapat dikualifikasikan 
sebagai perbuatan melawan hukum. Ketentuan Pasal 1365 BW ini pada prinsipnya bertujuan memberikan substansi perdata terhadap semua bentuk pelanggaran yang merugikan pihak lain.

Seseorang dianggap telah melanggar rahasia dagang orang lain jika ia memperoleh atau menguasai rahasia dagang tersebut dengan cara yang bertentangan dengan peraturan perundang-undangan yang berlaku. Pengecualian terhadap ketentuan pelanggaran rahasia dagang ini diberikan terhadap pengungkapan atau penggunaan rahasia dagang yang didasarkan untuk kepentingan pertahanan keamanan, kesehatan, dan keselamatan masyarakat, di samping berlaku pula untuk tindakan rekayasa ulang atas produk yang dihasilkan dari penggunaan rahasia dagang milik orang lain yang dilakukan sematamata untuk kepentingan pengembangan lebih lanjut produk yang bersangkutan.
Mengenai hak dan kewajiban subjek perjanjian diatur bahwa perusahaan pemberi Rahasia Dagang bersedia mengungkapkan kepada penerima informasiinformasi yang diperlukan dalam waktu tertentu dengan catatan penerima akan tetap merahasiakan dan tidak akan mengungkapkan kepada orang lain akan menggunakannya untuk kepentingan di luar perjanjian ini. Kewajiban merahasiakan ini juga berlaku terhadap perjanjianperjanjian selanjutnya yang mungkin dilakukan oleh pihak penerima. Pengecualian atau pembatasan atas isi perjanjian ini dimungkinkan jika informasiinformasi yang digunakan oleh penerima meliputi hal-hal sebagai berikut :

a. yang dimiliki penerima sebelum diterimanya perjanjian ini dan tidak diperoleh sebelumnya baik langsung maupun tidak langsung, menurut pengetahuan penerima atau wakil-wakilnya, dari 


\begin{tabular}{|c|c|}
\hline $\begin{array}{l}\text { pemberi atau wakil- } \\
\text { wakilnya; }\end{array}$ & $\begin{array}{l}\text { perjanjian ini yang dimiliki } \\
\text { dua arti strategis, yaitu : }\end{array}$ \\
\hline b. yang pada & Memberikan \\
\hline pengungkapan & dalam hubungan antara \\
\hline penerima & pemilik informasi \\
\hline wakilwakilnya & penerima informasi yang \\
\hline atau sesudah menjadi & menunjukkan batas-batas \\
\hline melalui & apa yang boleh dan tidak \\
\hline dilakukannya & boleh dilakukan \\
\hline kelalaian & penerima \\
\hline melakukan pada pihak & berkenaan dengan rahasia \\
\hline penerima atau para & perusahaan itu sehingga \\
\hline wakilnya bagian dari & para pihak mengetahui \\
\hline milik umum melalui & secara jelas batas hak dan \\
\hline publikasi atau lainnya; & kewajiban masing-masing \\
\hline c. atau yang disediakan & menghindari \\
\hline kepada penerima dan & terjadinya \\
\hline pihak-pihak & kesalahpahaman \\
\hline sebagai tanpa membatasi & penafsiran \\
\hline pada pengungkapan atau & kewajiban. \\
\hline penggunaannya. & b. Pembuatan \\
\hline Ketentuan-ketentuan kontrak & perlindungan \\
\hline yang dibuat seperti & informasi atas Rahasia \\
\hline dipaparkan sebelumnya & Dagang \\
\hline merupakan bagian penting & merupakan salah satu \\
\hline dari sistem perlindungan & langkah untuk menjamin \\
\hline Rahasia Dagang secara & kepastian hukum jika \\
\hline keseluruhan, sehingga dapat & dikemudian hari terdapat \\
\hline disimpulkan bahwa & sengketa \\
\hline pencantuman dan pembuatan & $\begin{array}{l}\text { karyawan atau pihak } \\
\text { ketiga. Perjanjian ini akan }\end{array}$ \\
\hline
\end{tabular}




\begin{abstract}
dapat dijadikan bukti otentik bahwa perusahaan memiliki informasi yang sangat rahasia sifatnya dan hanya dipergunakan untuk kegiatan bisnis perusahaan itu saja.
\end{abstract}

Kewajiban dalam memelihara kerahasiaan ini juga dapat ditempuh melalui ketentuan-ketentuan yang bersifat implisit. Pada prinsipnya hukum akan melindungi kerahasiaan itu berdasarkan asas-asas hukum perjanjian yang menyatakan bahwa perjanjian itu tidak hanya mencakup apa yang telah secara eksplisit diperjanjikan, tetapi mencakup juga kebiasaan-kebiasaan meskipun tidak secara tegas dinyatakan seperti tercantum dalam pasal 1347 BW yang berbunyi :

"Hal-hal yang menurut kebiasaan selamanya diperjanjikan dianggap secara diam-diam dimasukkan dalam persetujuan, meskipun tidak dengan tegas dinyatakan”.

Non-competition clause di berbagai Negara diberikan pembatasanpembatasan dalam keberlakuannya. Ada yang dibatasi dengan suatu Undang-undang maupun dengan kebijakan publik. Berdasarkan ketentuan hukum perjanjian di Indonesia, maka suatu perjanjian adalah sah jika memenuhi empat syarat sebagaimana yang diatur dalam Pasal 1320 BW. Hal ini berkaitan dengan klausula-klausula yang dimuat dalam suatu perjanjian. Isi suatu perjanjian kerja telah diatur dalam UU Ketenagakerjaan secara tegas. Dalam perwujudannya, noncompetition clause bisa merupakan bagian dari suatu perjanjian kerja atau dibuat secara terpisah dari perjanjian kerja. Tentunya jika klausula ini dicantumkan dalam perjanjian kerja maka harus merujuk pada ketentuan-ketentuan hukum yang berlaku. Ketentuan hukum di Indonesia tidak mengatur secara tegas mengenai pengaturan maupun pembatasan suatu non-competition clause. Sebenarnya tidak ada satu ketentuan hukum pun berdasarkan hukum Indonesia yang secara tegas melarang pencantuman noncompetition clause dalam perjanjian kerja selama para pihak sepakat menundukkan diri mereka terhadap klausula tersebut. 
Apabila upaya-upaya menjaga kerahasiaan telah dilakukan sesuai UU Rahasia Dagang, maka jika terjadi penggunaan atau pengungkapan informasi rahasia tersebut kepada pihak ketiga untuk kepentingan komersial, dapat diduga telah terjadi pelanggaran rahasia dagang. Pemegang Hak Rahasia Dagang atau penerima Lisensi dapat mengambil tindakan hukum baik secara perdata (Pasal 11 UURD) atau pidana (Pasal 17 UURD) terhadap siapa pun yang dengan sengaja dan tanpa hak melakukan pelanggaran rahasia dagang dengan cara mengungkapkan Rahasia Dagang, mengingkari kesepakatan atau mengingkari kewajiban tertulis atau tidak tertulis untuk menjaga Rahasia Dagang yang bersangkutan secara sengaja. Pelanggaran juga dianggap terjadi pada saat seseorang memperoleh atau menguasai Rahasia Dagang tersebut dengan cara yang bertentangan dengan peraturan perundang-undangan yang berlaku.

Teori kontrak merupakan dasar yang paling sering dikemukakan dalam proses pengadilan mengenai rahasia dagang.
Dalam sistem hukum Indonesia yang mengadopsi prinsip hukum Eropa Kontinental dianut bahwa kontrak atau perjanjian pada umumnya merupakan sumber perikatan (Pasal 1233 BW). Sesuai dengan Pasal 1338 BW bahwa perjanjian yang dibuat secara sah berlaku sebagai UndangUndang. Dengan demikian perjanjian-perjanjian yang dibuat para pihak tidak dapat ditarik kembali secara sepihak dan pelanggaran atas hal tersebut merupakan wanprestasi. Prinsipprinsip kontraktual ini pun dijadikan dasar perlindungan know-how dalam hukum Belanda yang mengklasifikasikan perlindungan sebelum kontrak ditutup, pada saat kontrak berjalan dan pada saat kontrak telah berakhir. Prinsip perlindungan berdasarkan hukum kontrak ini sangat relevan dengan bentuk perlindungan berdasarkan system hukum perburuhan atau hukum ketenagakerjaan. Hubungan antara pengusaha dan karyawan merupakan salah satu masalah penting berkenaan. Berkenaan dengan menjaga informasi rahasia dagang. Tingginya tingkat keluar 
masuk karyawan dari satu perusahaan ke perusahaan lain menyebabkan perlunya pengaturan rahasia dagang ini diintegrasikan ke dalam Undang-Undang Ketenagakerjaan. Teori ini pun terkait dengan masalah "orang dalam” perusahaan (insider trading). Perlu ditegaskan di sini bahwa suatu perjanjian yang dibuat oleh perusahaan dengan karyawannya yang isinya melarang penggunaan teknologi atau informasi yang telah diketahui secara umum atau merupakan public domain adalah suatu tindakan yang dianggap sebagai cacat hukum.

Jadi jelas bahwa dibentuk dan diundangkannya UURD dalam rangka mencapai tujuan adalah sebagai berikut :

a. Memajukan industri di Indonesia;

b. Menumbuhkan kembangkan invensi-invensi baru yang dapat memajukan industri tersebut;

c. Melindungi kepentingan hukum terhadap invensi, terutama invensi baru; d. Menjamin kepastian hukum bagi invensi tidak ada pelanggaran terhadap hak Rahasia Dagang miliknya.

Langkah-langkah yang diambil dalam melindungi Rahasia Dagang melalui sistem hukum kontrak yang dilakukan para pelaku bisnis adalah salah satu strategi yuridis untuk melindungi Rahasia Dagang itu sendiri, yang dapat dijadikan bukti bahwa pemiliknya secara sungguhsungguh telah melakukan perlindungan optimum terhadap Rahasia Dagang yang dimilikinya yang merupakan salah satu syarat informasi yang dikategorikan sebagai Rahasia Dagang. Segala informasi yang berkenaan atau yang menyangkut pelanggan, penjual keliling (vendor), pemberi lisensi (licensor), penerima lisensi (licensee), atau menyangkut pihak ketiga yang melakukan transaksi bisnis dengan perusahaan yang tertutup juga harus dirahasiakan kecuali jika dilakukan dengan prinsip tertulis.

Jadi bisa disimpulkan bahwa pentingnya perlindungan hukum untuk rahasia dagang adalah: 
1. Memberikan hak bagi pemilik rahasia dagang sebagai hak milik yang seluasluasnya tanpa mengganggu orang lain dan tidak bertentangan dengan peraturan perundang-undangan;

2. Pemilik hak rahasia dagang dapat mengalihkan haknya dan pemilik rahasia dagang tetap boleh melaksanakan sendiri atau memberi lisensi kepada pihak ketiga berkaitan dengan rahasia dagang yang dimilikinya selama lisensi diberikan;

3. Mencegah terjadinya kecurangan antara pelaku usaha sehingga terjadi persaingan yang sehat.

\section{SIMPULAN}

Berdasarkan hasil penelitian dan pembahasan di atas, diperoleh simpulan bahwa dengan dibuatnya suatu perjanjiaan kerahasiaan atau Non Disclosure Agreement menjadikan Para Pihak tersebut berkewajiban menjaga suatu informasi rahasia atau rahasia dagang yang diungkapkan oleh pihak yang mengungkapkan guna mennjaga dan melindungi Hukum Kekayaan Intelektual bagi Para Pihak.

\section{SARAN}

Seharusnya setiap pihak yang melakukan kerjasama baik dalam suatu perjanjian kerja antara pengusaha dan pekerja ataupun antara para pelaku usaha yang melakukan kerjasama bisnis harus mencantumkan kalusula mengenai "perjanjian kerahasiaan" ataupun dibuat perjanjian secara tersendiri mengenai Non Disclosure Agreement.

\section{DAFTAR PUSTAKA}

Abdulkadir Muhammad, Hukum Harta Kekayaan Intelektual, Rineka Cipta, Jakarta, 1994. 
Ahmad M. Ramli., Perlindungan Rahasia Dagang dalam UU No. 30/2000 dan

Perbandingan dengan beberapa Negara, CV. Bandar Maju, Bandung, 2001.

Ahmad M. Ramli, 2000, H.A.K.I:

Teori Dasar Perlindungan Rahasia Dagang,

Bandung: Mandar Maju.

Anonimous, Kitab Undang-Undang

Hukum Perdata - Burgerlijk

Wetboek,

Rhedbook Publisher, Jakarta, 2008.

H. Adami Chazawi., Tindak Pidana Hak Atas Kekayaan Intelektual (HAKI), Bayu

Media Publishing, Malang, 2007.

H. OK. Saidin., Aspek Hukum Hak Kekayaan Intelektual, PT. Raja Grafindo

Persada, Jakarta, 2004.

R. Subekti \& R. Tjitrosudibio., Kitab Undang-Undang Hukum Perdata, Pradnya

Paramitha, Jakarta, 1980.

Sudargo Gautama, Konvensikonvensi Hak Milik Intelektual Baru Untuk
Indonesia, Alumni, Bandung, 1997.

Sudikno Mertokusumo, Mengenal Hukum (Suatu Pengantar), 1991.

Toto Tohir Suriaatmadja, Masalah Bisnis Dalam Kajian Hukum, Fakultas Hukum Universitas Islam Bandung, Bandung, 2004.

Anastasia E. Gerungan, dalam jurnal "Perlindungan Hukum Terhadap Rahasia

Dagang Ditinjau Dari Aspek Hukum Perdata Dan Pidana Di Indonesia", Vol.22

No.5, Januari 2016.

Indriyana Dwi Mustikarini, dalam jurnal "Perspektif Hukum", Vol. 16 No. 1, Mei

2016.

Prof. Neni Sri Imaniyati, dalam jurnal “ Perlindungan HKI

Sebagai Upaya Pemenuhan Hak Atas Iptek, Budaya dan Seni”, Volume 17

No 1, Juni 2010.

Rizky Amalia, dalam Jurnal "NonCompetition Clause Dalam Perjanjian Kerja”,

Volume 26 No 2, MeiAgustus 2011. 
Asry Rismawaty, Non Disclosure Agreement Sebagai Perlindungan Hak Kekayaan Intelektua...

Syarifa Mahila, dalam jurnal “

Perlindungan Rahasia Dagang Dalam

Hubungannya

Dengan Perjanjian Kerja"

Vol.10 No.3, Tahun 2010 
Asry Rismawaty, Non Disclosure Agreement Sebagai Perlindungan Hak Kekayaan Intelektua... 